\author{
Danijela Marot Kiš \\ University of Rijeka \\ danijela.marot.kis@uniri.hr \\ ORCID: 0000-0003-0313-4170
}

\title{
Simuliranje demokracije: emancipacija demokratske krize u esejistici Dubravke Ugrešić*
}

\begin{abstract}
Marot Kiš Danijela, Simuliranje demokracije: emancipacija demokratske krize u esejistici Dubravke Ugrešić (Simulating Democracy: Emancipation of Democracy Crisis in Dubravka Ugrešić's Essays). "Poznańskie Studia Slawistyczne" 17. Poznań 2019. Publishing House of the Poznan Society for the Advancement of the Arts and Sciences, Adam Mickiewicz University, pp. 101-116. ISSN 2084-3011.
\end{abstract}

One of the central notions of the post-Yugoslav literature is the status of democracy in national states formed after the breakup of Yugoslavia. From the perspective of the exile, not only as banishment, but also as a liberating outside view into the once common social, cultural and political space, the post-Yugoslav writers question the social democracy praxis in their former home states comparing it to the social practices in the states of their current residence. In her books of essays, Dubravka Ugrešić ironizes different forms of social ideology in Croatia from the beginning of nineteen-nineties. Her writing recognizes the standards of European democracy accompanied with the ideological view into the questions of social rights, religion and language as the stumbling block of modern society. Ugrešić describes democracy as a notion hiding different things: the praxis of ruthless capitalist exploitation, loss of media freedom, media manipulation, the censorship of corporate capitalism, production of lies, modern slavery... (Don't take it personal, 2014), validating in her essays the importance of literature in disclosure of autocracy masked as democracy.

KeYwords: Dubravka Ugrešić; democracy; ideology; post-Yugoslav society; exile

\section{Demokracija i pogled izvana: demokratske prakse kao kulturno-književni stereotip}

U literaturi koju temeljem ranije prihvaćenoga zajedničkog društvenog, kulturalnog i etničkog prostora nazivamo postjugoslavenskom ${ }^{1}$ jednu od

${ }^{*}$ Ovaj je rad financirala Hrvatska zaklada za znanost projektom 2016-06-9548. This work has been fully supported by Croatian Science Foundation under the project 2016-06-9548.

${ }^{1}$ Pojmom postjugoslavenske književnosti referiramo na korpus tekstova u kojima je 
središnjih preokupacija predstavlja motiv egzila. Iskustvo trajne ili privremene izmještenosti, najčešće kao posljedice implicitne društveno-političke prisile ili zabrane, na različite načine u svoja djela upisuju pisci s područja nekadašnje, iščezle države. Pisanje u i o egzilu uključuje promišljanje odnosa jezika i zbilje, odnosno jezične izmještenosti (David Albahari), koncepta drugosti i dvojništva (Lidija Dimkovska, Aleksandar Hemon), moralne odgovornosti pamćenja i sjećanja (Daša Drndić) te fragmentiranosti osobnoga identiteta i opasnosti nacionalnih etiketa i stereotipa (Dubravka Ugrešić). Dovodeći u pitanje koncept nacionalne književnosti, ovi pisci vlastito iskustvo egzila kao dinamične i promjenjive perspektive koja zahtijeva stalno preispitivanje i prilagođavanje koriste kao kritički ,,pogled izvana“ na socijalne i kulturne prakse prošlosti i sadašnjosti napuštenoga prostora opredjeljujući se pritom za poziciju apolitičnosti i konvenciju diskursa „kulture šutnje“ (Albahari) ili pak jasne artikulacije kritike nacionalno-ideoloških procedura novonastalih demokracija (Ugrešić, Drndić).

U svom esejističkom opusu, koji obuhvaća zbirke Američki fikcionar (1993), Kultura laži (1993), Zabranjeno čitanje (2001), Nikog nema doma (2005), Karaoke kultura (2010) i Europa u sepiji (2013), Dubravka Ugrešić ironizira ideološke obrasce u Hrvatskoj od početka devedesetih godina dvadesetoga stoljeća dalje opravdavane potrebom približavanja standardima zapadnoeuropske liberalne demokracije, opisuje procese demokratizacije postkomunističkoga društva kroz usporedbu socijalnih obrazaca prošlosti i sadašnjosti te propituje značenje pojma multikulturalizma u socijalnim okruženjima Zapada i Istoka. Polazište dijela Ugrešićkine

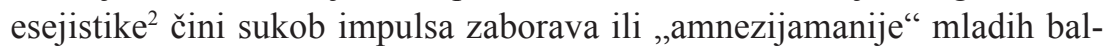
kanskih demokracija i muzealizacije prošlosti, odnosno mnemonizma koji opsesivno pamćenje promovira u okosnicu kolektivne identifikacije zasićene impulsima nacionalizma. Proizvod je opisanoga sukoba suvremeno

upisano iskustvo fragmentacije jednoga povijesno-politički determiniranoga kulturnog i etničkog prostora i socijalne zajednice. U kontekstu de-teritorijalizacije književnosti i njezina oslobađanja od etničkih i nacionalnih etiketa, o čemu piše Ugrešić, postjugoslavensko postaje krovni pojam koji podrazumijeva iskustvo izmještenosti, nepripadanja i odustajanja od jasno formiranih identitetskih obrazaca (jezičnih, nacionalnih, etničkih, teritorijalnih i drugih). U tom smislu su u ovaj pojam upisane oznake transnacionalnosti, višejezičnosti i egzila.

${ }^{2} \mathrm{U}$ fokusu su ovoga rada Ugrešićkine zbirke eseja Američki fikcionar i Nikog nema doma, u kojima se na analizu američke kulture nadovezuje opis (post)komunističkih, (pseudo)demokratskih i nacionalističkih socijalnih praksi u Hrvatskoj. 
simuliranje demokracije, odnosno pomno, no istovremeno i selektivno preispisivanje nacionalne prošlosti s ciljem deklarativnoga usvajanja liberalno-demokratskih praksi Zapada kao proklamiranoga sociopolitičkoga uzora.

Kritičko preispitivanje liberalno-demokratskih praksi u esejima Dubravke Ugrešić odvija se u dva smjera. U prvome Ugrešić nastupa kao javni kritičar socijalnih, političkih i kulturnih zbivanja u Hrvatskoj od početka devedesetih nadalje, dotičući se pitanja ratnih zbivanja i moralne odgovornosti/krivnje, uzroka i posljedica egzila kao socijalne prisile, ideološkoga manipuliranja jezikom, zlouporabe nacionalnih etiketa i problema osobnoga identificiranja u promjenjivom diskursu suvremenosti. Provodni je motiv ovoga dijela njezine esejistike simuliranje demokracije koje se odvija kao perpetuiranje društvenoga stereotipa multikulturalnosti naslijeđenoga iz doba komunizma ${ }^{3}$ i njegovo udruživanje s jakim nacionalističkim impulsom koji propagira kulturnu i socijalnu ekskluzivnost i vodi ka političkoj izolaciji. Drugi se smjer tiče pitanja autonomije i demokratičnosti književnosti u postkomunističkom zaokretu, odnosno pisanja kao aktivizma lišenoga nacionalnih i ideoloških predznaka i suprotstavljenoga diskriminatornim recepcijskim praksama nacionalnoga identificiranja. Demokratičnost književnosti kao aktivizma proizvodnje užitka u tekstu Ugrešić ovdje suprotstavlja kategorijama

\footnotetext{
${ }^{3}$ Socijalistički koncept multikulturalnosti, sažet u sloganu „bratstvo i jedinstvo“ (koji najbolje odražava njegovu deklarativnu narav) podrazumijevao je nadređivanje imaginarnoga iskustva zajedništva hegemonijskim praksama nacionalne ekskluzivnosti, odnosno niz socijalnih, političkih i kulturalnih praksi koje su osiguravale istost u raznolikosti, pa samim time i isključivanje koncepta Drugosti kao nepoželjnoga mjesta razlike. Neoliberalni pojam multikulturalnosti u okruženju nacionalnih post-jugoslavenskih državnih zajednica posuđuje isti koncept u kojemu se istost nadređuje raznolikosti, uvažavajući Drugost tek kao potvrdu vlastite nacionalne homogenosti. Stereotipnost i deklarativnost praksi multikulturalnosti podjednako u društvima Zapada i istočne Europe kroz paradigmu postkolonijalnoga stanja problematizira Boris Škvorc $(2010,77)$, tvrdeći ,da je i problem multikulturalizma iz žarišta manjinskih glasova u većinskom okružju dosta opterećen mitom o nacionalnoj posebnosti i konsolidaciji drugosti kao samosvojnom kontinuitetu (dakle esenciji a ne konstrukciji) i da u praksi ima dosta velikih problema s uključivanjem tako pozicioniranih žarišta u kakofoniju (papirnato) ravnopravnih glasova koji sudjeluju u proizvodnji zajedničke priče. To bi značilo da tip multikulturalnosti karakterističan za paradigme «novog svijeta» zapravo oblikuju mehanizmi slični onima što su vladali u pluralističkom društvu «paralelnih svjetova» unutar multinacionalnih država tradicionalne Europe, kao na primjer oni koje opisuje Andrić u svojim povijesnim romanima i novelama“.
} 
„,nacionalne“, „etničke“, „,emigrantske“ i „,egzilantske“ književnosti, kojima barataju književni kritičari i teoretičari, emancipirajući koncepciju transnacionalnoga pisanja kao nove, alternativne književne zone (Siva zona književnosti, Ugrešić, 2005, 190). Ključni pojam za razumijevanje te alternativne (sive) književne zone - u koju se Ugrešić i sama smješta - je ne-teritorijalnost, napuštanje tradicionalnoga koncepta prostorne ili, preciznije, geopolitičke upisanosti i određenosti književnoga stvaranja. Jaz između nacionalne i svjetske književnosti, ali isto tako književnopovijesno općeprihvaćenih pojmova poput književnoga kanona i manjinske književnosti Ugrešić premošćuje inzistiranjem na autentičnosti pisanja lišenoga prisile pripadanja određenom teorijskom konceptu, identitetskoj oznaci ili geografskom prostoru:

Dok su jedni, dakle, zabavljeni pitanjima književno-povijesnog, nacionalnog, etničkog i evropskog književnog identiteta, dotle u evropskim (i drugim) književnim međuprostorima raste velika siva zona ne-teritorijelne književnosti. U toj zoni obitavaju ,etnički neautentični“ autori, emigranti, migranti, egzilanti, pisci koji pripadaju dvjema kulturama istodobno, bilingvalni književnici koji stvaraju „niti ovdje niti ondje“, u svakom slučaju van granica svojih nacionalnih književnosti. Književnost sive zone ispisuju književnici koji pišu na svom materinskom jeziku okruženi jezikom zemlje-domaćina; i ti koji, odbacivši svoj materinski jezik, pišu na jeziku zemlje-domaćina; ti koji ruše jezične konvencije i slobodno se kreću između jezika i kultura prevodeći značenja; ti koji iz jezično-kulturnih mješavina stvaraju novi jezik i novu kulturu (Ugrešić, 2005, 189-190).

U oba slučaja Ugrešić demokratičnost, odnosno prakse liberalno demokratske nacionalne države, podvrgava oštroj kritici kao zastarjeli i potrošeni koncept, socijalni model koji je izgubio izvorno značenje i pretvorio se u niz deklarativnih postupaka i institucija svedenih na teorijske obrasce preuzete iz prošlosti, potvrđujući krizu liberalne ideološke hegemonije, čiji je trijumf najavljivan slomom komunističkih režima Istočne Europe (Fukuyama, 1992).

\section{Stereotipizacija kulture i (post)kolonijalni diskurs}

Analizom esejistike Dubravke Ugrešić kao narativnoga prikaza i kritike hegemonijsko-ideološkog diskursa (post)jugoslavenskoga društva te njegove usporedbe s kulturalno-socijalnim praksama Zapada bavile su se 
Nataša Kovačević u studiji Narrating Post/Communism (2008) i Jasmina Lukić u eseju Pisanje kao antipolitika (2001). Eseje sabrane u zbirkama Američki fikcionar i Nikog nema doma obje autorice interpretiraju kao poprišta usuglašavanja dvaju mitskih iskustava zbilje proizašlih iz niza stereotipnih predodžbi usmjerenih prema unutra - dakle samopoimanju vlastitih kulturnih, socijalnih i civilizacijskih obrazaca i prema van - odnosno stvaranju koncepcije Drugoga kao mjesta razlike.

Iskustvo implicitnoga političkog egzila ${ }^{4}$, opisano u zbirci eseja Američki fikcionar, Nataša Kovačević $(2008,173)$ tumači kroz sukob diskursa globalizacije kao tradicionalnog kolonijalnog narativa koji kulturni model Zapada nadređuje iskustvima kulturalne Drugosti i kritike toga istog diskursa. Iskustvo Drugosti promovirano globalizacijskim narativom unutar kojega se balkanski nacionalizmi povezuju s manjkom civiliziranosti, napretka i demokracije Kovačević $(2008,173)$ objašnjava praksama stereotipizacije koje nisu samo proizvod orijentalističkoga diskursa o Balkanu i Istočnoj Europi već i uloga koju spremno prihvaćaju mnogi balkanski egzilanti, što Ugrešić opisuje kroz stereotip Istočne Europe kreiran u vrijeme komunizma, no jednako djelatan i danas:

A ja ću prodati smeće iz komunističke ropotarnice, kaže novinarka. Ponudit ću im očekivanu sliku svijeta, stereotipe o životu iza ,„̌eljezne zavjese“, stereotipe o sivoj, odljuđenoj Istočnoj Europi koja čeka u redu za kiseli kupus (Ugrešić, 2002, 57).

U nacionalnim se državama nastalima nakon raspada jugoslavenske federacije redukcionizam orijentalističkoga diskursa ogledao u praksama prerade i preispisivanja kolektivnoga pamćenja, odnosno selektivnoga zaborava svega s predznakom ,jugokomunizma“, a s ciljem dokazivanja

${ }^{4} \mathrm{U}$ studiji The Rhetoric of Exile - Duress and the Imaging of Force Vladimir Zoric (2016) uvodi pojam implicitnoga egzila, koji nije povezan s mehanizmima kazne ili progona, već djeluje retroaktivno, kao posljedica neformalne prisile. Zorić konceptom implicitnoga egzila premošćuje tradicionalnu podjelu na prisilni (iz kaznenih mehanizama proizašli) i dobrovoljni egzil, tvrdeći kako se neformalnost prisile u njemu ostvaruje prešutnim konsenzusom uključenih strana.

(Osobno) iskustvo egzila koje pripovijeda Dubravka Ugrešić u svojoj esejistici moguće je tumačiti kao implicitnu formu izmještenosti, odnosno posljedicu neformalne prisile povezane s političkim i socijalnim pritiscima. Implicitni egzil tako postaje polazišna točka autoričine identifikacije i kritike socijalnih, političkih i kulturnih (pseudo)demokratskih praksi u domovini, odnosno temeljno iskustvo emancipacije demokratske krize. 
i potvrđivanja modernoga, jasno definiranog, demokratskog nacionalnog identiteta bliskoga socijalnim modelima Zapada. Dihotomijski prikaz identifikacijskoga iskustva egzilanta u Američkom fikcionaru Kovačević zaključuje isticanjem Ugrešićkine usporedbe tereta ideološkoga nasljeđa komunizma (Jugoslavije) i liberalne demokracije (Sjedinjenih Američkih Država) (Kovačević, 2008, 178). Disparatna sociokulturna i civilizacijska iskustva Ugrešić izjednačava u perspektivi koja zapadnjačku ideologiju masovne produkcije i propagande podjednako dobara kao i formi ljudskoga ponašanja povezuje s komunističkim ideologijama Istočne Europe te posebno populističkim nacionalizmom bivše Jugoslavije, pronalazeći njihov amblem u globalnom fenomenu kiča koji proklamiranu floskulu američkog multikulturalizma dovodi u vezu s parolom „bratstva i jedinstva“ (Kovačević, 2008, 179).

(Neo)kolonijalna perspektiva hegemonijskog orijentalističkog diskursa koju Kovačević koristi kao temeljnu premisu za iščitavanje Ugrešićkine esejistike počiva na principu stereotipizacije kao dvosmjernom procesu koji, svrstavajući kulturu Istočne Europe i Balkana u ograničavajući kontekst Drugosti lišen blagodati socijalnoga liberalno-demokratskog modela Zapada, istovremeno (pre)usmjerava njegovu oštricu ka (pseudo)demokratskim navadama društava Zapada, prvenstveno Sjeverne Amerike. U opisanome su dihotomijskom odnosu liberalna demokracija američkoga tipa i „meki“ model jugoslavenskog komunizma lice i naličje iste mitske slike svijeta i njezinih ograničavajućih procedura koje se perpetuiraju kulturnim stereotipima. Jaz između američkoga kulturnog mita (americane) i socrealističke kulture poslijeratne Jugoslavije počinje se smanjivati, kako opisuje Ugrešić u eseju Yugo-Americana, nakon mitskoga „ne“ Staljinu kao inauguraciji novoga modela komunizma. Rezultat je toga približavanja bio „osjećaj nejasnog globalnog bratstva“ (Ugrešić, 2002, 91), u kojemu se ogleda prodor američkog (konzumerističkog) mita u istočnoeuropsku svakodnevicu. Početkom rata koji će uslijediti nakon raspada Jugoslavije odnos dviju mitskih reprezentacija zbilje ponovo zadobiva novu dinamiku pod okriljem premisa orijentalističkoga diskursa: Zapad nastavlja perpetuirati vlastitu vizuru Drugosti, koju sada zbivanja na Balkanu obilato potvrđuju, ostajući pritom žuđenim mjestom blagostanja i demokracije za sve koji ostaju izvan njegovih granica: 
Nepredvidljiva zbilja nastavlja svoju igru s mitovima. Odavde promatram medijsko učvršćivanje „balkanskog“ mita koji se postupno slaže iz novinskih fotografija i televizijskih izvještaja. Televizijske snimke očajnih, bijednih, zapuštenih ljudi divlja pogleda odgovaraju „balkanskom“ stereotipu. [...] Dok se ovdje slaže mit o strašnom „Balkanu“ (zbilja, uostalom, i ne daje potvrde za drugo), dotle na Balkanu i nadalje živi američki mit! Balkanska zbilja odbija poistovjetiti se sa svojom slikom, draža joj je američka! (Ugrešić, 2002, 92).

Jasmina Lukić tekstove Američkoga fikcionara također analizira u ključu stereotipizacije sociokulturnoga iskustva i kolektivnoga identiteta u kontekstu Drugosti, kojoj pridaje dvostruku perspektivu, tvrdeći kako je riječ „o tekstovima primarno upućenim publici koja je u poziciji Drugoga u odnosu na teme o kojima se piše, ali pisanim takođe iz pozicije Drugosti“ (Lukić, 2001, 75). Dva pojavno različita svijeta, odnosno sociokulturna i civilizacijska iskustva, suprotstavljenost kojih je produbljena činjenicom da u vrijeme njihova nastajanja na prostorima bivše Jugoslavije traje rat, pripovijedanje u Ugrešićkinim esejima dovodi u vezu, nalazeći u obje situacije isti model stereotipnoga poimanja svakodnevice. Američka „kultura uspjeha“, koja sreću, zadovoljstvo i vlastite demokratske standarde promovira u same temelje civilizacijske superiornosti, i kultura Balkana, obilježena dijalogizmom s kulturom Zapada kroz koji nastoji dokazati vlastitu vrijednost i Drugost zamijeniti jednakošću, počivaju na sličnim procesima stereotipizacije kolektivnoga identiteta. Stereotipi na kojima počiva samopoimanje američke kulture, a kroz koje se povratno i oblikuje njezina vizura Istoka (Istočne Europe i Balkana) kao Drugosti i nastojanje toga istog Istoka da se riješi pripisane pozicije Drugosti i dokaže vlastitu vrijednost kroz usporedbu sa Zapadom počivaju na istim principima doslovnosti i odsutnosti autoironije, tvrdi Lukić (2001, 75). Ugrešić tako u nizu eseja očuđuje niz socijalnih i kulturnih praksi Zapada (opsjednutost izgledom, tjelesnom kondicijom i tijelom uopće, odlaske psihijatru, organiziranost) povezujući fragmente osobnoga iskustva jedne kulture kroz njihovu usporedbu s kulturnim i socijalnim paradigmama domicilne sredine. U oba je slučaja, zaključuje Lukić, na djelu stereotipizacija kulturnih i socijalnih praksi: „Nasuprot stereotipima koji oblikuju američku kulturu svakodnevice stoje stereotipi uz čiju se pomoć početkom devedesetih godina ruši jedan svet i grade novi, koji sebe žele da prikažu boljima od onog prethodnog“ (Lukić, 
2001, 80), pri čemu iskustvo američke kulture u domaćim okvirima nerijetko zadobiva ironijski obrat (tijelo kao estetski objekt u američkoj kulturi naspram objektivizacije tijela kao potrošnog materijala u ratu). Logika stereotipizacije ista je u velikim i u malim sredinama, naglašava Lukić (2001, 83), usmjeravajući svoju kritiku protiv stereotipnoga viđenja prošlosti/povijesti i pojednostavljenih rješenja njezinih konflikata.

Konflikti moderne kulture Istoka (na primjeru hrvatskih iskustava), proizašli iz takvoga stereotipnog poimanja vlastitih identitetskih obrazaca i njihova odnosa prema (hegemonijskoj) kulturi Zapada, temeljni su narativno-tematski model esejistike Dubravke Ugrešić. Iz vlastite pozicije „izvan“, odnosno egzilantskoga iskustva u kojemu se iskustvo pripadanja zamjenjuje pozicijom prilagodljivosti i pregovaranja, Ugrešić usmjerava oštricu ironijskoga narativa prema svim onim praksama i situacijama koje koriste povijesne, nacionalne i socijalne stereotipe kao osnovu identifikacije sebe i drugoga.

\section{Naličja (liberalne) demokracije}

Među pojednostavljenim i stereotipnim rješenjima koje Ugrešić problematizira u svojoj esejistici je nekritičko i deklarativno prihvaćanje liberalno-demokratskih praksi Zapada, koje je nakon sloma Jugoslavije obilježilo nastanak i kasniji razvoj nacionalnih država na Balkanu, među njima i Hrvatske. Optimistična perspektiva budućnosti zemalja Istočne Europe, koju je krajem osamdesetih godina prošloga stoljeća najavio Francis Fukuyama svojom tezom o pobjedi liberalnog i ekonomskog liberalizma $^{5}$ kao jedinoj alternativi totalitarnim režimima na zalasku, nije

${ }^{5}$ U knjizi End of History and the Last Man Fukuyama (1992, xi) razvija vlastitu tezu iz 1989., najavljenu u časopisu The National Interest, o liberalnoj demokraciji kao krajnjoj točki ideološke evolucije čovječanstva i finalnoj upravljačkoj formi lišenoj temeljnih unutarnjih kontradikcija koje su dovele do sloma svih poznatih totalitarnih režima. Postojanje nepravde i ozbiljnih socijalnih problema čak i u najrazvijenijim i najstabilnijim demokracijama Zapada (SAD, Francuska, Švicarska) Fukuyama opravdava nedostacima u implementaciji temeljnih demokratskih principa slobode i jednakosti, a ne pogreškama koje se tiču samoga liberalno-demokratskoga principa.

Fukuyamino tumačenje problema modernih liberalno-demokratskih režima jazom između socijalno-političkoga principa i njegove primjene može se primijeniti i na analizu 
našla potvrde u socijalnim praksama zemalja bivše Jugoslavije. Preuzeti model u okruženju novonastalih država doživio je stereotipnu interpretaciju, odnosno preuzet je doista samo kao teorijski, institucionalni okvir koji je u praksi interpretiran kroz prizmu snažnoga nacionalističkoga impulsa i pripadajućih mu socijalnih praksi marginalizacije i isključivanja Drugosti (nacionalnih, socijalnih, religijskih, manjinskih) te pod tranzicijskim okriljem ekonomske destabilizacije. Demokracija, kao proklamirana alternativa totalitarnoj Drugosti zaživjela je u ironiziranome obliku kao novi oblik totalitarizma s reperkusijama u svim domenama socijalnoga i kulturnog života, pa tako i u književnosti, odnosno umjetnosti uopće.

Indikativan je prikaz demokracije kao stereotipa kako ga Ugrešić opisuje u eseju Yugo-Americana iz zbirke Američki fikcionar. Rukovanje s ikonom klasičnoga holivudskog filma noir dvadesetih godina prošloga stoljeća Lauren Bacall Ugrešić tumači kao „simbolično zatvaranje jednog kulturnog kruga" (Ugrešić, 2002, 87). U kontekstu poslijeratnoga jugoslavenskog društva holivudski su filmovi predstavljali utjelovljenje kulturnoga mita zapadne demokracije koji je, osim filmovima i televizijom, bio posredovan još i drugim proizvodima moderne kulture: knjigama, modom, glazbom i umjetnošću. Demokracija je tako postala mitom perpetuiranim stereotipnim obrascima koji nisu (samo) preslikavali zbilju, već je i proizvodili: u totalitarnom političkom i socijalnom jugoslavenskom okruženju amblemi američke (demokratske) kulture (odjeća, literatura, filmovi) kreirali su iluziju slobode i globalne povezanosti kao kontrapunkta „tvrdim“ komunističkim režimima Istočne Europe:

Američki kulturni mit zakucao je na vrata poslijeratne Jugoslavije 1953. Te godine jugoslavenska kina prikazivala su američki film Bal na vodi s Esther Williams u glavnoj ulozi. Esther, dakako, nije ni slutila da je svojom lijepom, plivačkom nogom simbolički zalupila vrata nezvanu gostu, sovjetskoj socrealističkoj kulturi. Godine 1948. Tito je rekao svoje mitsko NE Staljinu, i Esther Williams, pionir ideološke borbe protiv hard-komunizma, poslužila je kao najefikasnija propagandna potvrda da je Tito bio u pravu (Ugrešić, 2002, 88).

kraha totalitarnih komunističkih režima Istoka, pa tako i Jugoslavije, u kojoj je proklamirani princip „bratstva i jedinstva“ iznevjeren ekspanzijom partikularnih nacionalističkih ideja, o čemu Ugrešić piše u svojoj esejistici. 
Istu aktivnost stereotipizacije zbilje, no ovaj puta u obrnutoj, negativnoj perspektivi globalizacijskoga demokratskog mita Ugrešić opisuje i u intervjuu iz 2000. godine (Biti izvan) referirajući na esej $U$ boljim kućama se o tome ne govori iz zbirke Kultura laži. Nekadašnja slika Zapadne Europe i Amerike u bivšoj Jugoslaviji, ali i cijeloj Istočnoj Europi iz vremena komunizma kao „rajske slike slobode, demokracije i imućnosti“ u novije je vrijeme zamijenjena krajnjošću negativnih stereotipa, koji iskazuju naličje demokracije i propituju opravdanost povjerenja u mitsku sliku Zapada promoviranu u komunizmu. Opisujući stereotipe demokracije Zapada iz doba komunizma i zapadnjačke stereotipe (post)komunističkoga društva ${ }^{6}$, Ugrešić u vezu dovodi „demokraciju diktature s diktaturom demokracije" te uspoređuje premise proklamirane jednakosti u oba sustava. U eseju Lolitas iz niza naslovljenoga Uvod u demokraciju (2007) opisana je proslava Titova rođendana $\mathrm{u}$ amsterdamskome baru. Nekolicina emigranata s područja bivše Jugoslavije barmenu objašnjava povod proslave, tumačeći kako je početak Titove diktature za njih značio dolazak demokracije. S razumijevanjem za barmenovu zbunjenost, Ugrešić zaključuje:

Kako sada da barmenu objasnim da se u novoj, postkomunističkoj demokraciji, u „demokraturi“", moram boriti za prava koja sam u komunističkoj diktaturi imala bez ikakve borbe?! Pravo na jednakost među spolovima; pravo na abortus; pravo da u školi ne pohađam vjeronauk, ako to neću; da ne nosim križ oko vrata, ako to neću; da se ne izjašnjavam koje sam nacionalnosti, ako to neću; pravo da ne mrzim Drugoga, ako to neću; pravo da glasno kažem da možda nisam živjela obasjana vatrometom demokracije, ali nije baš bilo ni suviše mračno, uostalom, u komunizmu je elektrifikacija bila na prioritetnom mjestu, nije li? (Ugrešić, 2007, 34).

Socijalni ustroj (jugoslavenskoga) komunističkog režima garantirao je određeni stupanj privole svojih građana, nudeći im sigurnost i stabilnost koja je u postkomunističkim demokratskim sustavima zamijenjena novim modelima diktature agresivnog i netolerantnog nacionalizma. $U$ tom

${ }^{6}$ U eseju Stereotipi Ugrešić opisuje koncept stereotipizacije kao temeljni mehanizam identifikacije drugoga, odnosno princip (ne)uvažavanja različitosti: „Odrasla sam u zemlji u kojoj se bratstvo i jedinstvo njegovalo kao zjenica oka, ali su se ujedno njegovali i stereotipi o pripadnicima tog bratstva. [...] S odlaskom iz zemlje mislila sam da napuštam polje stereotipa. Prevarila sam se, stereotipi oko mene umnožili su se. Danas me okružuju ne samo stereotipi sredina u kojima boravim, nego i oni koje stanovnici tih sredina imaju o - Balkanu“ (Ugrešić, 2005, 26). 
smislu postkomunistički model demokracije Ugrešić opisuje kao diktaturu nacionalne ideologije koja vlastite građane lišava temeljnih egzisencijalnih prava implicitno ih prisiljavajući na paradigmu postkomunističke svakidašnjice - egzil. Zapadna Europa i Sjeverna Amerika, kao ciljana mjesta političkih i ekonomskih emigranata, nude pak svoju varijantu demokracije oblikovanu politikom integracije te prilagodbe kulturnih, etničkih i religijskih identiteta. Osnovna je premisa takve demokracije - pravo na vlastiti identitet $^{7}$ - preslika proklamiranoga jedinstva iz Titove parole, preobraženoga u stereotipnu zamjenu stvarnim socijalnim praksama potvrđene jednakosti, što Ugrešić opisuje u eseju Uvod u robovlasničko društvo:

Jer sve ove ljude ovdje ujedinjuje ista klasa. Svi su oni ovdje - i bijeli Holanđani, i tamnoputi Marokanci, i crni Surinamci, i žuti Kinezi - odjeveni u istu odjeću, čija cijena ne prelazi desetak evra, svi imaju isti ukus, svi kupuju iste jeftine sofe, iste plastične igračke za svoju djecu, iste televizore, svi nose na zaglavcima iste satove. Svi su oni „smeće“, trash, lišeno svijesti o vlastitu položaju. Lukavi političari i još lukaviji popovi podmetnuli su im igračku: pravo na religijski, nacionalni, etnički identitet. Turcima se čini da je neobično važno to što su Turci, Marokancima to što su Marokanci, Holanđanima to što su Holanđani, Hrvatima to što su Hrvati, Srbima to što su Srbi... I svi oni žvaču i natežu svoj sveti identitet kao žvakaću gumu, i ne videći da je u pitanju jeftin supstitut, ne shvaćajući da je to jedino što mogu žvakati, jer svi pripadaju istoj klasi, underclass, klasi deklasiranih (Ugrešić, 2007, 14).

Tezu o novome robovlasništvu kao dnu liberalne demokracije u postkomunističkim društvima Ugrešić nastavlja u eseju Don't take it personal (2014). Opisujući nastup slovenske grupe Zaklonišče prepeva, koja

\footnotetext{
${ }^{7}$ Odnosom identiteta i integriteta te prava na (nacionalni) identitet i identiteta kao obaveze (prisile) bavi se Ugrešić u eseju Identitet: „Moji bivši zemljaci toliko su se derali i kukali, toliko urlali i zapomagali braneći svoj nacionalni identitet, toliko su se udarali u prsa istog identiteta, i personalno i kolektivno, toliko su lajali i režali bljeskajući očnjacima i psećim ogrlicama, da naprosto nisam mogla da ih ne čujem. Isprva sam mislila, neka ih, ljudima valjda treba taj nacionalni, etnički, državni identitet, neka ga imaju, što u tome može biti loše. Bila sam zbilja PC (politički korektna), poštovala sam njihovu težnju za identitetom. Ja ga osobno nisam imala, niti ga imam, niti mi takva stvar fali. A onda su krenuli jedni na druge kao bijesni psi, opet u ime obrane svoga identiteta. I mene su, kad smo već kod toga, uzeli na zub. Kako možeš bez identiteta, režali su na mene. [...] Promijenila sam mjesto boravka, pomoglo je, ali ne osobito. Identitet udišem i dalje kao peludnu prašinu, ta riječ i dalje zvoni oko mene kao mantra“" (Ugrešić, 2005, 77). Pravo na slobodu osobne i kolektivne identifikacije kao jedna od temeljnih premisa demokracije u okvirima se suvremenih nacionalnih država pretvara u nužnost i mjesto razlike, a ne slobode ili jednakosti.
} 
u pjesmi Samo da prođe demokratija partizanskim vokabularom sociopolitičke kritike napada temeljne premise postjugoslavenske demokracije, zaključuje kako su upravo odsutnost autentičnoga glasa i nemogućnost artikuliranoga protesta paradigme suvremenoga društva, u kojemu snagu kritike čine „,banalna preciznost artikulacije problema i izražavanje nemogućnosti protesta kroz pozivanje na protest" (Ugrešić, 2014):

I eto, dogurali smo do kraja, do samog dna demokracije. Što je više protesta, tim su protesti manje efikasni, čim je više kanala za odašiljanje poruka, tim se poruke manje čuju. Svi živimo u Hyde Parku, svatko od nas ima pravo na svoj Speaker's corner. Politički jezik izgubio je snagu uvjeravanja, postao je govor ispražnjen od značenja: ljudi se grupiraju prema instinktu krda, udesno ili ulijevo, vjerujući da će zahvaljujući lijevima ili desnima uspjeti sačuvati posao, ili naći posao, ili pak dogurati do osigurane penzije. Jezik političkog protesta izgubio je snagu uvjerenja, protestanti dođu i prođu. Parole, golotinja, cvijeće u kosi, obnažene ženske grudi, živi Isusi na križu, samospaljivanje, honkonški kišobrani - sve to načas bljesne u novinama i ekranima i brzo potone u mrak (Ugrešić, 2014).

Pravo na identitet, pravo na različitost, na protest, na kritiku - samo su deklarativna prava lišena istinske snage demokratskoga aktivizma i osuđena na isprazno ponavljanje zbog činjenice na koju Ugrešić u pozadini svakoga svojega eseja upozorava: da su klasna pozicija i hegemonijske prakse moći (ekonomske ili političke) preuzele upravljačku ulogu u liberalno-demokratskim režimima, koji su tako postali paravani suvremenoga totalitarizma.

\section{Siva zona književnosti: moguće mjesto otpora hegemonijskim praksama identificiranja}

Situacija simulirane demokratičnosti preslikava se i u kontekst suvremene literarne produkcije i recepcije. U nizu eseja pod zajedničkim naslovom Što je europsko u europskoj književnosti iz zbirke Nikog nema doma (2005) Ugrešić opisuje podjelu na „,autentičnu“ i „neautentičnu“ zonu književnosti, određenu potrebom pripisivanja etničkih i nacionalnih oznaka književnome stvaralaštvu. Isto načelo stereotipnoga pripisivanja identiteta i identitetskih obrazaca, koje se u okvirima suvremene europske liberalne demokracije tumači kao pravo na različitost, prepoznatljiv je 
i kao koncept literarnog etiketiranja i svrstavanja u kategorije određenoga (hegemonijskoga) sustava. Etnički, nacionalni, religijski i jezični predznaci i određenja poduprta institucionaliziranim sustavima poput izdavačkih kuća i književnih nagrada, ali i same književne kritike, pogoduju stvaranju takva sustava u kojemu svaki pisac pripada određenoj kategoriji prema kojoj se oblikuje i recepcijski kontekst, pa zatim i (estetska) vrijednost njegova stvaranja. Pravo na razliku pritom postaje obavezom koja podrazumijeva točno određeni horizont očekivanja iznevjeravanje kojega uzrokuje marginalizaciju, nezadovoljstvo i neprihvaćanje. Funkcionalnost takvoga „demokratičnog“ sustava narušavaju pisci koje Ugrešić svrstava u „sivu zonu književnosti“, proglašavajući ih „disfunkcijom u sistemu“ koji ne funkcionira kao mnoštvo razlika, već kao razlika mnoštva:

I sve bi bilo u redu da ne postoje non-mainstream pojedinci, disfunkcije u sistemu, ti koji razaraju stereotipe u kulturi, o tome što ona jest, i kakva bi trebala biti. Takvi pojedinci nadrastaju kulturne promotore, managere i kulturnu birokraciju EU koja se muči nad pitanjima europskog kulturnog identiteta. Takvi pojedinci nadrastaju svoje kritičare $\mathrm{i}$ interpretatore, univerzitetske profesore i svoje čitaoce. Drugim riječima: nitko ne zna što da s njima radi (Ugrešić, 2005, 187).

U kontekstu literarne produkcije i recepcije u Hrvatskoj odnos je autohtonog i alohtonog, tvrdi Ugrešić, prevagnuo u korist promocije ,etnički autentične" književnosti kao devetnaestostoljetnog koncepta potpomognutoga iz ekonomskotržišne zone posuđenim sloganom „Čitajmo hrvatsko!“ U isto je vrijeme književnost polarizirana između ovih krajnosti i nesnalaženja oko teorijskoga etiketiranja etnički-jezično-nacionalno neartikulirane zone suočena i s procesom tržišne demokratizacije, u kojemu ozbiljnoj književnosti prijeti sustavna marginalizacija u domenu, kako kaže Ugrešić, male svite lojalnih saveznika: slučajnih čitaoca, prevodioca, teoretičara i povjesničara umjetnosti.

Pesimističnu perspektivu umjetnosti demokratizacije i demokratizacije umjetnosti, u kojoj je u socijalizmu proklamirana jednakost zamijenjena liberalno-demokratskom obavezom na različitost, a estetski užitak pragmatičkim učinkom, Ugrešić opisuje u eseju Književna geopolitika:

Evropa je iskusila različite estetske kanone, umjetničke koncepte i periode: iskusila je duge periode elitne, visoke kulture, a zatim i vrijeme „,mehaničke reprodukcije“ i deaurizacije umjetnosti, da bi se na kraju našla u totalnom rasulu koncepata, ali i u žustroj 
dinamici rasula gdje se miješaju demokratizacija umjetnosti i vladavina tržišta, jaka dominacija masovne kulture, koja je mahom američka, a s tim u vezi i geopolitizacija kulture, a zatim i ostaci tradicionalističkih kulturnih koncepata i njihova politizacija. U svom tom rasulu postoji i potreba Evrope, koja kao glavno ideološko ljepilo koristi upravo kulturu, da tu svoju kulturu reartikulira i redefinira (Ugrešić, 2005, 196).

Reartikuliranje kulturne i književne mape Europe, tradicionalno (pred)određene dijalektikom zapadnoga kanona i marginalnih kultura istoka podrazumijeva, tvrdi Ugrešić, ne samo novo poimanje margine i Drugosti, već i napuštanje tradicionalnoga koncepta nacionalne književnosti kao redundantne i reducirajuće identifikacijske prakse. Naime, hegemonijski impulsi, koji su se u doba komunističkoga režima odnosili na promociju državne ideologije, a danas isticanje ideala nacionalnoga jedinstva, temelje se na načelima uključivanja i isključivanja, pri čemu se ,značajna društvena energija usmerava na obeležavanje Drugoga kao stranog tela u društveno poželjnom kolektivitetu“ (Lukić, 2001, 95). Siva zona o kojoj piše Ugrešić, svrstavajući u nju pisce koji i kao empirijski autori i kao narativni glasovi (modeli autora) odbijaju vlastito pisanje podrediti ili pak staviti u funkciju promoviranja (nacionalnoga) identiteta, mjesto je gdje se odvija suvremena depolitizacija književnosti, mjesto razlike i otpora, strano tijelo dominantnih kulturno-književnih praksi.

I dok evropski književni teoretičari - zbunjeni brojem sve poznatijih književnih imena koja ne pripadaju „ni ovamo ni onamo“ - pokušavaju artikulirati uzbudljive migracijske procese u književnosti potpomažući se u nedostatku boljih čak i starom Goetheovom odrednicom „,svjetske književnosti“, dotle se mnogi evropski „etnički čisti“ književnici gnijezde u prašnom konceptu nacionalne književnosti, uživajući kao miševi u kolutu sira. Rupe u siru sve su, međutim, veće, sira je sve manje, a babilonska buka novih, nerazumljivih, zastrašujućih koncepata (post-national units, transnational units, cross-border mobilizations, paranational units...) koja dopire izvana sve je glasnija (Ugrešić, 2005, 191-192).

Kritička oštrica eseja Dubravke Ugrešić, usmjerena protiv društveno-političkih i kulturno-književnih praksi liberalne demokracije zapadnoga modela kao suvremenoj inačici totalitarizma u književnosti traži (i u transnacionalnoj njezinoj orijentaciji pronalazi) moguće mjesto demokratizacije, otpora tradicionalnim hegemonijskim praksama koje su podjednako obilježile odnos Zapada prema Istoku kao i unutrašnje socijalne, kulturne i ideološke procese postkomunističkih zemalja. 
Teorijska čitanja i interpretacije Ugrešićkine esejistike u ključu postkolonijalnoga disursa (Kovačević) i stereotipnosti (multi)kulturalnih praksi koje funkcioniraju pod okriljem različitih tumačenja i (ne)prihvaćanja Drugosti (etničkih, nacionalnih, kulturnih) (Lukić) polazišta su za razumijevanje njezine kritike suvremenih socijalno-političkih praksi hegemonizacije i homogenizacije koje se odvijaju pod deklarativnim okriljem demokra(tiza)cije i multikulturalnosti, a koje svoj odraz pronalaze i u domeni književnoga stvaranja kao značajnome mjestu mogućega otpora dominantnim praksama vremena. Siva zona književnosti, koju Ugrešić propagira kao moguće mjesto otpora hegemonijskim praksama identificiranja, u kojima (deklarativno prihvaćena) Drugost još uvijek predstavlja okosnicu razlikovanja i podjele na autohtono i alohtono, domaće i strano, većinsko i manjinsko, dio je mogućega rješenja krize neuspjeloga liberalno-demokratskoga modela Zapada, najavljujući emancipaciju nepripadanja i odustajanja od čvrsto zadanih identifikacijskih modela kao paradigmu suvremenoga multikulturalizma, ne kao homogenoga mnoštva Drugosti pod okriljem većinske kulture, već kao divergentne i identitetskim obrascima neopterećene zajednice razlika.

\section{Literatura}

Fukuyama, F. (1992). End of History and the Last Man. New York: The Free Press.

Kolanović, M. (2008). Kome treba 'identitet'? Esejistika Dubravke Ugrešić. „Književna republika" br. 3-4, str. 153-162.

Kolanović, M. (2011). »Naš« obračun sa socijalizmom. Postsocijalistička književna artikulacija (europskoga) socijalizma. „Studia Lexicographica“ god. 5, br. 1 (8), str. 86-102.

Kovačević, N. (2008). Narrating Post/Communism: Colonial Discourse and Europe's Borderline Civilization Potentialities. London - New York: Routledge.

Lukić, J. (1996). Women-Centered Narratives in Contemporary Serbian and Croatian Literatures. U: Engendering Slavic Literatures. Ed. P. Chester, S. Forrester. Bloomington - Indianapolis: Indiana University Press, str. 223-245.

Lukić, J. (2001). Pisanje kao antipolitika. „Reč“ br. 64, str. 73-102.

Polić, V. (2018). Dubravka Ugrešić: Boundaries of (Post)Memory, Self, and Nation. U: Women's Narratives and the Postmemory of Displacement an Central-Eastern Europe. Ed. S. Mitroiu. Palgrave: Macmillan, str. 173-196.

Škvorc, B. (2010) Multikulturalnost i multikulturalizam u postkolonijalnom „stanju stvari “: Dislocirani identitet, pričanje zajednice, književnost i druge Hrvatske. „Časopis za hrvatske studije“ vol. 6, str. 69-112. 
Ugrešić, D. (2000). Biti izvan (pitanja postavljala Ana Ristović). „Reč“ br. 60, str. 111-122 .

Ugrešić, D. (2002). Američki fikcionar. Zagreb: Konzor - Beograd: Samizdat B92.

Ugrešić, D. (2005). Nikog nema doma. Zagreb: Devedeset stupnjeva.

Ugrešić, D. (2007). Uvod u demokraciju. „Reč“ br. 75, str. 5-39.

Ugrešić, D. (2014). Don 't take it personal. „Peščanik.net“. https://pescanik.net/dont-take-it-personal/. 25.11.2018.

Zorić, V. (2016). The Rhetoric of Exile. Duress and the Imaging of Force. Cambridge: Legenda. 